\title{
ANALISIS PENERAPAN KURIKULUM 2013 DALAM MENINGKATKAN KUALITAS PEMBELAJARAN EKONOMI DI SMA NEGERI SE-KOTA PALEMBANG
}

\author{
Oleh: Neta Dian Lestari \\ (UNIVERSITAS PGRI PALEMBANG)
}

neta_obyta@yahoo.com

\begin{abstract}
Abstrak-Indonesia adalah negara yang selalu berusaha mengikuti perkembangan Era Global dan persuasi, setiap pergantian Kepala Negara (Presiden) juga Pergantian Menteri Pendidikan Perubahan Kurikulum pun dilakukan. Permasalahan yang dihadapi adalah, Kurikulum di Indonesia telah mengalami beberapa perubahan, hingga akhirnya kurikulum baru lahir pada tahun 2013 yang merupakan kurikulum berdasarkan kompetensi dan karakter. Menjadi bermasalah di setiap sekolah, khususnya di Sekolah Umum di Kota Palembang. Sesuai dengan permasalahannya, penelitian ini bertujuan untuk menganalisis "Bagaimana Penerapan Kurikulum 2013 dalam Meningkatkan Mutu Pembelajaran Ekonomi di SMA Negeri-Palembang". Metode yang digunakan adalah dengan menggunakan metode deskriptif untuk mengetahui perencanaan dan pelaksanaan kurikulum 2013 yang dilakukan oleh guru dalam pelaksanaan dan peningkatan pembelajaran ekonomi di SMA Negeri Kota Palembang. Berdasarkan hasil penelitian, bahwa pada saat pembelajaran guru telah menerapkan kurikulum 2013, terbukti dari 95,83\% sesuai dengan pedoman Kurikulum yang dibuat oleh Pemerintah berjalan dengan baik, dan hanya 4,67\% yang cukup sesuai.
\end{abstract}

Kata Kunci:: Penerapan Kurikulum 2013, Meningkatkan Kualitas, Pembelajaran Ekonomi

\begin{abstract}
Indonesia is a country that always try to follow the development of Global Era and persuasion, every change of Head of State (President) also Change of Education Minister of Curriculum Change was done. Problems encountered are, Curriculum in Indonesia has undergone several changes, until finally the new curriculum was born in 2013 which is a curriculum based on competence and character. Being troubled in every school, especially in Public Schools in Palembang City. In accordance with the problem, this study aims to analyze "How Application of Curriculum 2013 in Improving the Quality of Economic Learning in SMA Negeri-Palembang". The method used is by using descriptive method to know the planning and implementation of curriculum 2013 conducted by teachers in the implementation and improvement of economic learning in the State Senior High School of Palembang. Based on the results of the research, that at the time of teacher learning has implemented the curriculum
\end{abstract}


2013, proven from $95.83 \%$ in accordance with Curriculum guidelines made by the Government goes well, and only $4.67 \%$ is quite appropriate.

Keywords: Application of Curriculum 2013, Improve Quality, Economic Learning

\section{PENDAHULUAN}

Kualitas suatu bangsa sangat ditentukan oleh Sumber Daya Manusia (SDM). Kualitas SDM tersebut bergantung pada kualitas pendidikan dan peran pendidikan untuk menciptakan masyarakat yang cerdas, damai, terbuka dan demokratis.

Oleh sebab itu, komponen dari sistem pendidikan nasional harus senantiasa dikembangkan sesuai dengan kebutuhan dan perkembangan yang terjadi, baik pada tingkat lokal, nasional maupun global. Salah satu komponen yang penting dari sistem pendidikan yaitu kurikulum. Kurikulum menurut UU No. 20 tahun 2003 tentang Sistem Pendidikan Nasional adalah seperangkat rencana dan peraturan mengenai tujuan, isi, dan bahan pelajaran serta cara yang digunakan sebagai pedoman penyelenggaraan pembelajaran untuk mencapai tujuan pendidikan tertentu. (Permendikbud 2016).

Fadlillah (2014:13), juga mengemukakan bahwa Kurikulum adalah sebuah wadah yang akan menentukan arah pendidikan. Dari beberapa penjelasan kurikulum diatas, dapat disimpulkan bahwasannya kurikulum merupakan bagian yang sangat berperan penting dalam mengembangkan ide dan rancangan menjadi proses pembelajaran sehingga mampu mencapai tujuan pendidikan yang dicita-citakan selama ini.

Negara Indonesi merupakan negara yang selalu berusaha mengikuti perkembangan zaman dan persaingan global, setiap pergantian Kepala Negara (Presiden) juga Pergantian Mentri Pendidikan Pergantian Kurikulum pun selalu dilakukan. Masalah yang di hadapi yaitu, Kurikulum di Indonesia telah mengalami beberapa kali perubahan secaraberturut-turut yaitu pada tahun 1947, tahun 1964, tahun 1968, tahun 1973, tahun 1975, tahun 1984, tahun 1994, tahun 1997 (revisi Kurikulum 1994), dan tahun 2004 (Kurikulum Berbasis Kompetensi), serta kurikulum 2006 (Kurikulum Tingkat Satuan Pendidikan). Dalam perjalanannya, pemerintah sebagai regulator melihat perlu adanya pengembangan pada Kurikulum Tingkat Satuan Pendidikan (KTSP tahun 2006) yang sudah berlangsung selama kurang lebih 6 tahun tersebut, dalam rangka memajukan mutu dan kualitas pendidikan nasional. Oleh sebab itu, akhirnya lahir kurikulum baru di tahun 2013 yang merupakan kurikulum berbasis kompetensi dan karakter, hal itu menjadi problematika di setiap sekolah, 
terutama di Sekolah Negeri di Kota Palembang.

Lahirnya kebijakan baru ini, tentunya tetap harus disikapi secara positif jangan sampai menjadi beban guru dan satuan pendidikan yang berkecimpung dan menaruh perhatian terhadap pendidikan. Saat ini perbincangan Kurikulum 2013 merupakan topik terhangat dalam dunia pendidikan di tanah air. Pada awal tahun ajaran 2013/2014, pemerintah telah memberlakukan Kurikulum 2013 untuk diujicobakan ke beberapa sekolah yang terakreditasi A dan B, yaitu pada pendidikan Dasar (SD), Menengah (SMP) dan Atas (SMA/SMK).

Dalam Kurikulum 2013, untuk meningkatkan kualitas pembelajaran tidak lepas dari proses pembelajaran, proses pembelajaran merupakan salah satu elemen dari standar proses yang mengalami perubahan guna pencapaian keberhasilan pembelajaran dan pembentukan kompetensi siswa. Pemerintah dalam Peraturan Menteri Pendidikan dan Kebudayaan Republik Indonesia No. 65 Tahun 2013 tentang standar proses pendidikan dasar dan menengah menjelaskan bahwa dalam mengimplementasikan proses pembelajaran di kurikulum 2013 pada satuan pendidikan harus diselenggarakan secara interaktif, inspiratif, menyenangkan, menantang, memotivasi siswa untuk berpartisipasi aktif, serta memberikan ruang yang cukup bagi prakarsa, kreativitas, dan kemandirian sesuai dengan bakat, minat, dan prkembangan fisik serta psikologis siswa.

Dari penjelasan diatas, dapat dikatakan bahwa dalam meningkatkan kualitas pembelajaran, proses pembelajaran merupakan salah satu rangkaian kegiatan yang penting untuk pencapaian keberhasilan pembelajaran dan pembentukan kompetensi siswa dimana dilaksanakan oleh guru sebagai pendidik dan siswa sebagai peserta didik dalam kegiatan pembelajaran dengan menggunakan sarana dan fasilitas pendidikan yang ada untuk mencapai tujuan yang telah ditetapkan dalam kurikulum, sehingga dalam hal ini, pihak-pihak yang terkait dan berkepentingan seharusnya senantiasa responsif terhadap dinamika yang terjadi dalam dunia pendidikan.

Tujuan Penelitian adalah rumusan kalimat yang menunjukkan adanya suatu hal yang diperoleh setelah penelitian selesai (Arikunto, 2010:97). Sesuai dengan permasalahan yang dikemukakan diatas, maka penelitian ini bertujuan untuk menganalis "Bagaimana Penerapan Kurikulum 2013 dalam Meningkatkan Kualitas Pembelajaran Ekonomi di SMA Negeri Se-Kota Palembang". Manfaat yang diharapkan dari penelitian ini adalah: Bagi Sekolah, hasil penelitian ini diharapkan dapat memberi masukan dan evaluasi serta menjadi bahan 
pertimbangan bagi sekolah dalam meningkatkan kualitas pendidikan dalam penerapan kurikulum 2013 khususnya pada mata pelajaran ekonomi demi kemajuan sekolah yang bersangkutan. Bagi Guru, dapat mengoptimalkan kinerjanya dalam meningkatkan kualitas pembelajaran, serta dapatmengetahui kendalakendala yang dihadapi dan dapat mencari solusi dari kendala yang ada sehingga menjadikan motivasi guru untuk meningkatkan keprofesionalan guru dan inovasi dalam proses pembelajaran. Selain itu, juga dapat digunakan sebagai informasi tentang perkembangan pendidikan khususnya dalam implementasi Kurikulum 2013. Bagi Siswa hasil penelitian ini dapat dijadikan pedoman dalam praktik keterampilan dikelas sesuai dengan kurikulum 2013

Sekolah Menengah Atas Negeri yang melaksanakan Kurikulum 2013 dan merupakan salah satu sekolah percontohan dalam pelaksanaan Kurikulum 2013 di kota Palembang pada tahun ajaran 2013/2014 guna meningkatkan prestasi siswanya. Menurut Fadlillah (2014:16) Kurikulum 2013 adalah kurikulum baru yang melalui diterapkan pada tahun pelajaran 2013/2014. Kurikulum ini adalah pengembangan dari kurikulum yang telah ada sebelumnya, baik Kurikulum Berbasis Kompetensi yang telah dirintis pada tahun 2004 maupun Kurikulum Tingkat Satuan Pendidikan pada tahun. Pada
Kurikulim 2013 yang menjadi titik tekan adalah adanya peningkatan dan keseimbangan soft skills dan hard skills yang meliputi aspek kompetensi sikap, keterampilan, dan pengetahun.

Kurikulum 2013 adalah kurikulum yang melakukan penyederhanaan, dan tematikintegratif, menambah jam pelajaran yang bertujuan untuk mendorong peserta didik atau siswa, mampu lebih baik dalam melakukan observasi, bertanya, bernalar dan mengkomunikasikan

(mempersentasikan), apa yang mereka peroleh atau mereka ketahui setelah menerima materi pembelajaran dan diharapkan siswa kita memiliki kompetensi sikap, keterampilan, dan pengetahuan jauh lebih baik. Mereka akan lebih kreatif, inovatif, dan lebih produktif, sehingga nantinya mereka bisa sukses dalam menghadapi berbagai persoalan dan tantangan dizamannya, memasuki masa depan yang lebih baik (Abdullah, 2015:239). Kurikulum 2013 merupakan tindak lanjut dari kurikulum berbasis kompetensi (KBK) yang perna di uji coba pada tahun 2004 (Mulyasa, 2015:66). Kurikulum 2013 adalah kurikulum baru yang melalui diterapkan pada tahun pelajaran 2013/2014. Kurikulum ini adalah pengembangan dari kurikulum yang telah ada sebelumnya, baik Kurikulum Berbasis Kompetensi yang telah dirintis pada tahun 2004 
maupun Kurikulum Tingkat Satuan Pendidikan pada tahun. Dari beberapa penjelasan diatas dapat disumpulkan bahwa kurikulum 2013 adalah Penyempurnaan dari kurikulum sebelumnya bertujuan untuk menjadikan siswa lebih aktif dan hasil belajar menjadi optimal.

Fadlillah (2014:25), mengenai tujuan kurikulum 2013, secara khusus dapat penulis uraikan sebagai berikut: (1) Meningkatkan mutu pendidikan dengan menyeimbangkan hard skills dan soft skills melalui kemampuan sikap, keterampilan dan pengetahuan dalam rangka mengahdapi tantangan global yang terus berkembang. (2) Membentuk dan meningkatkan sumber daya manusia yang produktif, kreatif dan inovatif sebagai modal pembangunan bangsa dan negara Indonesia. (3) Meringankan tenaga pendidik dalam menyampaian materi dan menyiapkan administrasi mengajar, sebab pemerintah telah menyiapkan semua komponen kurikulum beserta buku teks yang digunakan dalam pembelajaran. (4) Meningkatkan peran serta pemerintah pusat dan daerah serta warga masyarakat secara seimbang dalam menentukan dan mengendalikan kualitas dalam pelaksanaan kurikulum tingkat satuan pendidikan. (5) Meningkatkan persiangan yang sehat antar-satuan pendidikan tentang kualitas pendidikan yang akan dicapai. Sebab sekolah diberikan keluasan untuk mengembangkan Kurikulum 2013 sesuai dengan satuan pendidikan, kebutuhan peserta didik, dan potensi daerah.

Menurut Kunadar (2013:3) Tahap pertama dalam pembelajaran menurut standar proses yaitu menyusun perencanaan atau perangkat pembelajaran. program atau rencana yang harus disusun oleh guru sebelum melakukan pembelajaran antara lain: (1) Pragram Tahunan merupakan rencana penetapan alokasi waktu satu tahun untuk mencapai tujuan (SK dan KD) yang telah ditetapkan. Penetapan alokasi waktu diperlukan agar seluruh kompetensi dasar yang ada dalam kurikulum seluruhnya dapat dicapai oleh siswa. Program semester adalah program yang berisikan garis-garis besar mengenai hal-hal yang hendak dilaksanakan dan dicapai dalam semester tersebut. Program semester merupakan jabaran dari program tahunan. Isi dari program semester adalah tentang bulan, pokok bahasan yang hendak disampaikan, waktu yang direncanakan, dan keteranganketerangan. (3) Silabus merupakan acuan penyusunan kerangka pembelajaran untuk setiap bahan kajian mata pelajaran. (4) Rencana Pelaksanaan Pembelajaran (RPP) adalah rencana kegiatan pembelajaran tatap muka untuk satu pertemuan atau lebih. RPP dikembangkan dari silabus untuk mengarahkan kegiatan pembelajaran 
peserta didik dalam upaya mencapai Kompetensi Dasar (KD).

\section{METODOLOGI PENELITIAN}

\section{Populasi dan Sampel}

Populasi adalah wilayah generalisasi yang terdiri atas: obyek/subyek yang mempunyai kualitas dan karakteristik tertentu yang ditetapkan oleh peneliti untuk dipelajari dan kemudian ditarik kesimpulannya, (Sugiyono, 2010:61). Populasi dalam penelitian ini yaitu: Seluruh sekolah Negeri yang ada di kota Palembang yaitu sebanyak 23 sekolah.

Sampel adalah bagian dari jumlah dan karakteristik yang dimiliki oleh populasi, (Sugiyono, 2010:62). Dalam menentukan sampel peneliti menggunakan purposive sampling. Sampel bertujuan dengan cara mengambil subjek bukan didasarkan atas strata, random atau daerah tetapi didasarkan adanya tujuan tertentu (Arikunto,2015:183). Sampel dalam penelitian ini yaitu:

Tabel 1. SMA Negeri yang Diteliti

\begin{tabular}{|c|c|c|}
\hline No. & Sekolah & Guru \\
\hline 1 & SMA Negeri 1 Palembang & 3 \\
\hline 2 & SMA Negeri 2 Palembang & 3 \\
\hline 3 & SMA Negeri 3 Palembang & 3 \\
\hline 4 & SMA Negeri 4 Palembang & 3 \\
\hline 5 & SMA Negeri 5 Palembang & 3 \\
\hline 6 & SMA Negeri 8 Palembang & 3 \\
\hline 7 & SMA Negeri 9 Palembang & 3 \\
\hline 8 & SMA Negeri 11 Palembang & 3 \\
\hline 9 & SMA Negeri 15 Palembang & 3 \\
\hline 10 & SMA Negeri 19 Palembang & 3 \\
\hline \multicolumn{2}{|c|}{ JUMLAH } & $\mathbf{3 0}$ \\
\hline
\end{tabular}

\section{Metode Penelitian}

Metode penelitian merupakan metode deskriptif. Metode deskriptif adalah data yang berbentu kalimat, atau gambar (Sugiyono, 2010:23). Berdasarkan jenis penelitian yang dilakukan oleh peneliti maka metode yang digunakan adalah dengan menggunakan metode deskriptif untuk mengetahui perencanaan dan pelaksanaan kurikulum 2013 yang dilakukan guru dalam melaksanakan dan meningkatkan pembelajaran ekonomi di kelas XI IPS SMA

Negeri Se-Kota Palembang.

\section{Teknik Pengumpulan Data}

Teknik pengumpulan data merupakan langkah yang paling utama dalam penelitian, karena tujuan utama dari penelitian adalah mendapatkan data, tanpa mengetahui teknik pengumpulan data, maka penelitian tidak akan mendapatkan data yang memenuhi standar data 
yang ditetapkan, (Sugiyono, 2010:308).

Sutrisno (dalam Sugiyono, 2016:145), mengatakan bahwa observasi merupakan suatu proses yang kompleks, suatu proses yang di susun dari berbagai proses biologis dan psikologis. Dalam penelitian ini observasi digunakan untuk, menganalisis penerapan kurikulum 2013 oleh Guru.

Arikunto (2010:201)

menyatakan bahwa "Dokumentasi, dari asal kata dokumen, yang artinya barang-barang tertulis. Didalam melaksanakan metode dokumentasi, peneliti menyelidiki benda-benda tertulis seperti buku-buku, majalah, dokumen, peraturan-peraturan, notulen rapat, catatan harian, dan sebagainya" dokumentasi dalam penelitian ini penelitian ini adalah nilai rapot siswa kelas $\mathrm{X}$ semester 1 mata pelajaran Ekonomi.

Tabel 2. Interval Predikat Berdasarkan KKM

\begin{tabular}{|c|c|c|c|c|}
\hline \multirow{2}{*}{ KKM } & \multicolumn{4}{|c|}{ Predikat } \\
\cline { 2 - 5 } & $\mathbf{D}=$ Kurang & C = Cukup & B = Baik & A = Sangat Baik \\
\hline 60 & $\mathrm{~N}<60$ & $60 \leq \mathrm{N} \leq 75$ & $76 \leq \mathrm{N} \leq 85$ & $86 \leq \mathrm{N} \leq 100$ \\
\hline 65 & $\mathrm{~N}<65$ & $65 \leq \mathrm{N} \leq 75$ & $76 \leq \mathrm{N} \leq 85$ & $86 \leq \mathrm{N} \leq 100$ \\
\hline 67 & $\mathrm{~N}<67$ & $67 \leq \mathrm{N} \leq 75$ & $76 \leq \mathrm{N} \leq 85$ & $86 \leq \mathrm{N} \leq 100$ \\
\hline 70 & $\mathrm{~N}<70$ & $70 \leq \mathrm{N} \leq 75$ & $76 \leq \mathrm{N} \leq 85$ & $86 \leq \mathrm{N} \leq 100$ \\
\hline
\end{tabular}

Sumber : Dinas Pendidikan kota Palembang

\section{Teknik Analisis Data}

Kegiatan observasi dalam penelitian ini peneliti melakukan ceklis guru mengajar berdasarkan Kurikulum 2013 dengan cara melihat proses pembelajaran Guru Ekonomi dengan di dampingi oleh stap Kurikulum. Dari hasil observasi peneliti melakukan perhitungan dengan Menghitung frekuensi persentase pada tiap kriteria penilaian sebagai berikut:

$$
\mathrm{p}=\frac{\mathrm{f}}{\mathrm{n}} \times 100 \%
$$

Keterangan :

$$
\mathrm{P}=\text { Persentase }
$$

$\mathrm{F}=$ Frekuensi pada tiap kriteria penilaian

$\mathrm{N}=$ Jumlah

\section{HASIL PENELITIAN}

Deskriptif Tempat Penelitian

Penelitian ini dilaksanakan di 10 SMA Negeri di Kota Palembang yaitu: $\quad$ SMA Negeri 1,2,3,4,5,8,9,11,15 dan SMA Negeri 19 di Kota Palembang. Dari tanggal 24 Juli 2017 sampai dengan 16 September 2017. (Stajbłk arorpt:43) penelitian ini peneliti meminta bantuan kepada Mahasiswa Program Studi Pendidikan Akuntansi yang sedang melaksanakan kegiatan PPL2 
di sekolah tersebut, yang mana mahasiswa diminta untuk mengumpulkan data berupa dokumentasi RPP dan silabus, melakukan wawancara langsung dengan guru mata Pelajaran, melakukan observasi ke kelas guru mengajar dan melakukan ceklis observasi, serta meminta izin melihat nilai rapot siswa sebagai dokumentasi dan wawancara singkat.

Berdasarkan hasil tabel Observasi diatas, bahwa pada saat pembelajaran guru telah menerapkan kurikulum 2013, terbukti dari $95,83 \%$ sudah Sesuai dengan pedoman Kurikulum yang dibuat oleh Pemerintah, di laksanakan dengan baik. Dan hanya 4,67\% saja yang cukup Sesuai, sedangkan yang tidak Sesuai tidak ada. Berarti dapat disimpulkan penerapan Kurikulum 2013 di kota Palembang sudah Sesuai dengan pedoman yang ditetapkan oleh Pemerintah dan di terapkan dengan Sangat Baik oleh guru-guru yang ada di Kota Palembang.

\section{Deskriptif Data}

Data Observasi

Tabel 3. Hasil Ceklis Observasi Guru Mata Pelajaran Ekonomi

\begin{tabular}{|c|c|c|c|c|}
\hline \multirow[b]{2}{*}{ No } & \multirow[b]{2}{*}{ Aspek yang diamanti } & \multicolumn{3}{|c|}{ Jumlah Sekolah } \\
\hline & & $\begin{array}{l}\text { Tidak } \\
\text { Sesuai }\end{array}$ & $\begin{array}{l}\text { Cukup } \\
\text { Sesuai }\end{array}$ & Sesuai \\
\hline 1 & Identitas Mata Pelajaran & - & - & 30 \\
\hline 2 & Indikator dan tujuan pembelajaran & - & - & 30 \\
\hline 3 & Materi pembelajaran & - & 2 & 28 \\
\hline 4 & $\begin{array}{l}\text { Metode dan langkah-langkah } \\
\text { pembelajaran }\end{array}$ & - & 2 & 28 \\
\hline 5 & Media/alat pembelajaran & - & 2 & 28 \\
\hline 6 & Sumber Pembelajaran & - & 2 & 28 \\
\hline 7 & Penilaian Hasil belajar & - & 1 & 29 \\
\hline 8 & Instrumen Nilai Hasil belajar & - & 1 & 29 \\
\hline & Jumlah & - & 10 & 230 \\
\hline & F \% & 0 & 4,67 & 95,83 \\
\hline
\end{tabular}

Sumber : Hasil Olahan Peneliti

\section{Data Dokumentasi}


Tabel 4. Kualiatas Pembelajaran dengan Kurikulum 2013 SMA di

\begin{tabular}{|c|l|c|c|}
\hline No & \multicolumn{1}{|c|}{ Sekolah } & Nilai & Kategori \\
\hline 1 & SMA Negeri 1 & $76 \leq \mathrm{N} \leq 85$ & Baik \\
\hline 2 & SMA Negeri 2 & $76 \leq \mathrm{N} \leq 85$ & Baik \\
\hline 3 & SMA Negeri 3 & $76 \leq \mathrm{N} \leq 85$ & Baik \\
\hline 4 & SMA Negeri 4 & $76 \leq \mathrm{N} \leq 85$ & Baik \\
\hline 5 & SMA Negeri 5 & $76 \leq \mathrm{N} \leq 85$ & Baik \\
\hline 6 & SMA Negeri 8 & $76 \leq \mathrm{N} \leq 85$ & Baik \\
\hline 7 & SMA Negeri 9 & $76 \leq \mathrm{N} \leq 85$ & Baik \\
\hline 8 & SMA Negeri 11 & $76 \leq \mathrm{N} \leq 85$ & Baik \\
\hline 9 & SMA Negeri 15 & $76 \leq \mathrm{N} \leq 85$ & Baik \\
\hline 10 & SMA Negeri 19 & $76 \leq \mathrm{N} \leq 85$ & Baik \\
\hline
\end{tabular}

Sumber: hasil Olahan Peneliti

Peneliti tidak bermaksud membandingkan nilai dari setiap Sekolah yang peneliti jadikan sampel penelitian, peneliti hanya melihat kualitas pembelajaran secara keseluruhan yang di lakukan disetiap sekolah, oleh karena itu peneliti untuk mengetahui kualitas pembelajaran dengan menggunakan kurikulum 2013, peneliti menggunakan rentang nilai.

Berdasarkan tabel di atas, dapat terlihat jelas bahwa kualitas pembelajaran yang guru hasilkan dari penerapan kurukulum 2013 rata-rata adalah $76 \leq \mathrm{N} \leq 85$ dalam Kategori Baik. Hal ini menunjukan bahwa hasil belajar Ekonomi siswa dengan penerapan Kurikulum 2013 adalah

\section{Baik.}

\section{PEMBAHASAN}

Berdasarkan hasil penelitian Penerapan Kurikulum 2013 dalam meningkatkan kualitas pembelajaran ekonomi di SMA Negeri Se-Kota Palembang di ambil dari hasil belajar siswa yaitu nilai rapor siswa yang Alhamdulillah memiliki Kualitas dalam Kategori Baik, walaupun Kurikulum 2013 baru secara maksimal diterapkan tetapi sekolah Negeri di Kota Palembang dapat dengan Baik meningkatkan Kualitas pembelajaran ekonomi siswa. Berdasarkan hasil rapor, penelitipn melakukan wawancara singkat dengan guru untuk mengetahui stategi apa yang di gunakan sehingga hasil belajar siswa dalam Kategori Baik. Dari hasil wawancara, dapat disimpulkan bahwa dalam kegitan pembelajaran untuk meningkatkan hasil belajar siswa Guru menyampaikan materi dengan jelas lalu langsung bertanya kepada siswa, memberikan materi dengan menggunakan media seperti vidio, gambar yang menarik, dan lain-lain agar siswa memperhatikan dan tidak 
bosan dalam proses pembelajaran. Guru juga menciptakan suasana yang menyenangkan sehingga siswa tidak takut untuk bertanya,serta pada saat menjelaskan Guru menyelipkan penjelasan yang menantang untuk di tanya, dan Guru tidak sungkan memberi reward dan pujian kepada siswa yang bertanya serta tidak meremeh dan menyalakan jawaban dari siswa supaya mereka bersemangat untuk bertanya lagi. Setelah itu siswa di bagikan kelompok dan mulai menggali pengetahuan yang lebih luas lagi seperti dari internet, buku, film dll. Guru mendorong siswa agar mau memaparkan hasilnya kedepan kelas dengan memberi pujian pada siswa yang mau maju kedepan dan membantu untuk membuat kesimpulan dalam kelompok mereka. Penjelasan di atas didukung oleh hasil observasi dan didukung oleh hasil ceklis dokumentasi RPP, bahwa Guru sudah menerapkan pendekatan scientifik dan langkahlangkah pembelajaran 2013 seperti mengamati, menanya,mengumpulkan dan mengasosiasikan, dan mengomunikasikan hasil. Berdasarkan hasil Observasi terhadap Guru SMA Negeri Se-Kota Palembang, bahwa pada saat pembelajaran guru telah menerapkan kurikulum 2013, terbukti dari 95,83\% sudah Sesuai dengan pedoman Kurikulum yang dibuat oleh Pemerintah, di laksanakan dengan baik, dan hanya $4,67 \%$ saja yang Cukup Sesuai, sedangkan yang tidak Sesuai tidak ada.

Proses yang dapat dilakukan dengan menggunakan pendekatan scientific dan tematik-integratif. Langkah-langkah dalam mengimplementasikan pendekatan ini sebagai berikut:

Berdasarkan hasil penelitian Observasi penelitian bahwa Guru membuka secara luas dan bervariasi kesempatan peserta didik untuk melakukan pengamatan dan pengalaman belajar melalui berbagai kegiatan: melihat, menyimak, mendengar, dan membaca. Guru memfasilitasi peserta didik untuk melakukan pengamatan, melatih mereka untuk memperhatikan (melihat, membaca, dan mendengar) hal yang penting dari suatu benda atau objek. Hal ini didukung oleh hasil wawancara bahwa dalam kegiatan pembelajaran agar siswa tidak bosan mengamati guru menggunakan media seperti vidio, mempariasikan model atau metode pembelajaran, gambar yang menarik, dan lain. Serta di dukung oleh hasil ceklis dokumentasi bahwa guru menggunakan media, alat atau sumber belajar sesuai dengan tujuan pembelajaran, materi, dan siswa.

Guru memberikan kesempatan kepada peserta didik untuk bertanya mengenai apa yang telah dilihat, disimak, dibaca, dan dialami. Guru membimbing peserta didik untuk dapat mengajukan pertanyaan: pertanyaan tentang yang hasil 
pengamatan objek yang konkret sampai kepada yang abstrak berkenan dengan fakta, konsep, prosedur, ataupun hal lain yang abstrak. Pertanyaan yang bersifat fakta sampai kepada pertanyaan yang bersifat menjawab. Hal ini di dukung oleh hasil wawancara bahwa Guru membuka sesi pertanyaan kepada siswa dan supaya siswa tidak takut bertanya. Guru tidak merasa sungkan untuk memberi reward dan pujian serta tidak menyalakan jawaban siswa, agar siswa tersebut bersemangat untuk bertanya lagi.

Tindak lanjut dari bertanya adalah menggali dan mengumpulkan informasi dari berbagai sumber melalui berbagai cara. Untuk itu, siswa dapat membaca buku yang lebih banyak, memperhatikan fenomena atau objek yang lebih teliti, atau bahkan melakukan eksperimen. Dari kegiatan tersebut terkumpul sejumlah informasi. Hal ini di dukung oleh hasil wawancara bahwa Guru mendorong siswa agar mengumpulkan informasi dari berbagai sumber supaya pengetahuan siswa bertambah luas.

Kegiatan berikutnya adalah siswa menuliskan atau menceritakan apa yang ditemukan dalam kegiatan mencari informasi, mengasosiasikan, dan menemukan pola. Hasil tersebut disampaikan dikelas dan dinilai oleh guru sebagai hasil belajar peserta didik atau kelompok peserta didik tersebut. Hal ini di dukung oleh hasil wawancara bahwa Guru mendorong siswa agar memaparkan hasil dari apa yang mereka kerjakan ke depan kelas dan Guru memberi pujian serta melakukan penilaian.

Berdasarkan penjelasan di atas bahwa pelaksanaan Penerapan Kurikulum 2013 dapat meningkatkan kualitas pembelajaran ekonomi di SMA Negeri Se-Kota Palembang di dukung oleh hasil belajar siswa yaitu nilai rapor, rata-rata nilai dalam kategori BAIK yaitu $76 \leq \mathrm{N} \leq 85$.

\section{KESIMPULAN}

Berdasarkan hasil penelitian yang telah dilakukan tentang Analisis Penerapan Kurikulum 2013 dalam Meningkatkan Kualiatas Pembelajaran Ekonomi dapat peneliti simpulkan bahwa:

1. Pelaksanaan pembelajaran Kurikulum 2013 benar dapat meningkatkan Kualitas pembelajaran belajar siswa, terbukti dari hasil dokumentasi nilai rapor dalam kategori Baik.

2. Pelaksanaa penerapan Kurikulum 2013 oleh Guru Ekonomi sudah terlaksana dengan Baik dan sesuai dengan Kurikulum 2013, walapun masih terdapat kesulitan karena seringnya terjadi revisi dan kesesuaian dengan alokasi waktu. Walaupun demikian Guru berusaha menerapkan Kurikulum 2013 dengan sebaik mungkin.

\section{SARAN}


Berdasarkan hasil di atas peneliti memberikan saran sebagai berikut:

1. Guru sebaiknya selalu mempersiapkan diri dalam menghadapi perubahanperubahan kurikulum yang sering terjadi Selalu meningkatkan pemahaman mengenai Kurikulum 2013 dengan mengikuti seminar, workshop, pelatihan mengenai Kurikulum 2013 atau mempelajari buku-buku Kurikulum 2013.

2. Sekolah hendaknya secara berkala mengadakan pelatihan atau seminar Kurikulum 2013.

3. Penelitian ini dapat di jadikan referensi atau peneliti lanjutan.

\section{UCAPAN TERIMAKASIH}

Universitas PGRI Palembang, atas bantuan dan dukungannya sehingga penelitian ini dapat dilaksakan dengan lancar.

\section{DAFTAR PUSTAKA}

Arikunto, Suharsimi. 2010. Prosedur Penelitian Suatu Pendekatan Praktik.jakarta : PT Rineka Cipta .

Edi Sutrisno. 2016. Manajemen Sumber Daya Manusia. Jakarta : Prenadamedia Group.

Fadlillah, M 2014. Implementasi Kurikulum 2013 dalam pembelajaran SD/MI, SMP/MTs, \& SMA/MA. Yogyakarta: Ar-Ruzz Media.

Mulyasa, E 2015. Pengembangan dan Implementasi akaurikulum
2013.Bandung: $\quad$ PT.Remaja Rosdakarya Offset.

Permendikbud. 2016. Peraturan menteri pendidikan dan kebudayaan nomor 22 tahun 2016 tentang standar proses pendidikan dasar dan menengah.

Kunandar, 2013. Penilaian auntentik (penilaian hasil belajar peserta didik berdasarkan kurikulum 2013). Jakarta: PT.Raja Grafindo Persada.

Sani,Ridwan Abdullah. 2015. Pembelajaran Saintifik untuk Implementasi Kurikulum 2013. Jakarta:PT.Bumi Aksara.

Sugiyono, 2010. Statistik Untuk Penelitian. Bandung: Alfabeta.

http://file.upi.edu/Direktori/FPBS/JU R. PEND. BAHASA DAER $\mathrm{A} \overline{\mathrm{H}} / 19760 \overline{7} 31200112 \overline{1}-$ ADE SUTISNA/SEJARAH P ERKEMB._KURIKULUM.pd $f$. 